\title{
Otwartość i funkcja dydaktyczna słownika języka specjalistycznego
}

\author{
Joanna Konieczna-Serafin \\ Uniwersytet Jagielloński w Krakowie \\ joanna.konieczna@uj.edu.pl
}

\begin{abstract}
Streszczenie
Artykul dotyczy otwartości opisu leksykograficznego w dwóch niemiecko-polskich i polskoniemieckich słownikach języka specjalistycznego z zakresu gospodarki. W ramach zagadnienia otwartości badaniu poddano funkcje dydaktyczna stownika. W analizie obrana została perspektywa użytkownika filologa, a za kontekst użycia słownika dwujęzycznego przyjęto komunikację $w$ języku niemieckim jako języku obcym. Badanie otwartości słownika przeprowadzono na trzech płaszczyznach: makro-, mikro- $i$ mediostruktury, nawiazujac przy tym do kontrastywnych badań $w$ zakresie słowników języka ogólnego i specjalistycznego prowadzonych $w$ Polsce (np. Fraczek, Lipczuk 2004) oraz do badań międzynarodowych, szczególnie germanistycznych (np. Wiegand 1998a; Bergenholtz, Tarp, Wiegand 1999; Wiegand 2005; Wiegand 2013). Na wybranych przykładach ukazano, w jakim zakresie typ makrostruktury, dyrekcjonalność $i$ poliakcesywność danych leksykograficznych sprzyjaja realizacji funkcji dydaktycznej słownika. Analiza przeprowadzona na płaszczyźnie makrostrukturalnej ukazała, że typem makrostruktury ukierunkowanej na dydaktyke języka obcego jest układ haset gniazdowo-alfabetyczny. Analiza mikrostrukturalna naświetlita stabe strony opisu leksykograficznego, np. niewystarczajace ukazanie relacji paradygmatycznych $w$ obrębie artykutu hasłowego. W badanych stownikach stwierdzono dominację cechy monodyrekcjonalności nad bidyrekcjonalnościa.
\end{abstract}

Słowa kluczowe: słownik języka specjalistycznego, dydaktyka języka niemieckiego, funkcje stownika dwujęzycznego

\section{Abstract}

Openness and the Didactic Function of a Specialized Dictionary

The article focuses on openness of lexicographic description in two German-Polish and PolishGerman LSP dictionaries of economics. As part of the issue of openness, the didactic function of a dictionary was examined. In the analysis, the adopted user's perspective was that of a philologist, while the context of use of a bilingual dictionary was set as communication in German as a foreign language. The dictionary openness study was conducted on three levels, namely, on a macro-, micro- and mediostructural level, with a reference to contrastive studies on general-language and LSP dictionaries conducted in Poland (e.g. Fraczek, Lipczuk 2004) and international research, especially German studies (e.g. Wiegand 1998a; Bergenholtz, 
Tarp, Wiegand 1999; Wiegand 2005; Wiegand 2013). Selected examples served as a basis for presenting the extent to which the type of macrostructure, directionality and polyaccessibility of lexicographic data contribute to the performance of the didactic function of a dictionary. The analysis conducted on macrostructural level showed word-formative nest-alphabetical order of entries to be a type of macrostructure oriented at foreign language didactics. The microstructural analysis shed light on weaknesses of lexicographic description, such as insufficient presentation of paradigmatic relations within an entry article. In the examined dictionaries, the feature of monodirectionality was found to prevail over bidirectionality

Keywords: specialized dictionary, didactics of the German, the functions of a bilingual dictionary

\section{Wstęp}

Przedmiotem badania w niniejszym artykule są dwa bilingwalne niemiecko-polskie i polskoniemieckie słowniki języka specjalistycznego. Słowniki te zbadane zostały pod kątem ich otwartości, ujmowanej tutaj jako dostępność zawartych w nich danych leksykograficznych dla użytkownika, a także otwartość na konteksty w opisie leksykograficznym. Polskie określenie dostępność stosowane jest tutaj jako odpowiednik niemieckiego terminu Datenakzessivität w rozumieniu rozwiniętym przez Wieganda $(2005,2013)$, który na gruncie germanistycznych badań w zakresie słowników wyróżnia monoakcesywność i poliakcesywność dzieła leksykograficznego.

W badaniu przyjęto perspektywę otwartości słownika dwujęzycznego jako jego przydatności w dydaktyce języka specjalistycznego. Celem badania jest uchwycenie, za pomocą jakich struktur (mikro-, makro- lub mediostruktur) słownik specjalistyczny przekazuje treści językowe (np. informacje dotyczące łączliwości semantycznej wyrazu hasłowego z innymi jednostkami leksykalnymi) oraz niejęzykowe (np. informacje encyklopedyczne). W dalszej części badanie ma na celu określenie, czy wybrany typ makrostruktury może w szerszym lub węższym zakresie sprzyjać rozwijaniu kompetencji językowych. Badanie nie skupia się natomiast na ocenie zgodności semantycznej między wyrazami hasłowymi a ich ekwiwalentami prezentowanymi w słowniku. Ciekawe oraz przydatne, zarówno dla leksykografii praktycznej, jak i dla dydaktyki przekładu spostrzeżenia dotyczące relacji między hasłem a ekwiwalentami - w odniesieniu do bilingwalnego słownika języka ogólnego i specjalistycznego - poczynili m.in. Lipczuk (1997), de Groot (1999), Dębski (2001), Gugała (2002), Szubert (2003), Lipczuk (2004), Nadobnik (2010), Piotrowski (2011), Kopczyńska (2013), Lipczuk (2017). 


\section{Konteksty użycia i użytkownicy słownika}

W niemieckojęzycznej literaturze przedmiotu (Wiegand 1998a: 369) wyróżnia się trzy główne konteksty użycia słownika, z czego istotnym dla tematu poruszanego $\mathrm{w}$ tym artykule jest pierwszy z nich, tj. korzystanie ze słownika jako źródła wiedzy ${ }^{1}$ pomocnego $\mathrm{w}$ procesie produkcji bądź recepcji tekstu, w procesie przekładu tekstu lub nauki języka²

Treść, zakres i sposób prezentowania danych leksykograficznych zależny jest od przeznaczenia słownika, czyli jego ukierunkowania na konkretnego odbiorcę. Określenie przeznaczenie nie jest tożsame $\mathrm{z}$ terminem dyrekcjonalność, definiowanym $\mathrm{w}$ dyskursie metaleksykograficznym jako ukierunkowanie słownika ze względu na język użytkownika. W metaleksykografii dotyczącej słowników języka specjalistycznego wyróżnia się dwa główne typy użytkownika: specjalistę oraz laika (Tarp 1994: 232). W obrębie tych dwóch grup różnicuje się użytkowników w oparciu o poziom wiedzy specjalistycznej oraz poziom kompetencji językowych. W ten sposób wyróżnia się cztery następujące typy: użytkownika określanego jako laik o niskim stopniu wiedzy specjalistycznej i niskich kompetencjach językowych, użytkownika określanego jako laik o niskim stopniu wiedzy specjalistycznej i wysokich kompetencjach językowych, uzytkownika-specjalistę o wysokim stopniu wiedzy specjalistycznej i niskim poziomie kompetencji językowych oraz użytkownika-specjalistę o wysokim stopniu wiedzy specjalistycznej i wysokim poziomie kompetencji językowych.

W kontekście powyższego podziału użytkowników nasuwa się pytanie, w której grupie sytuuje się student filologii germańskiej oraz w jakim stopniu sprawności zdobywane w ramach kursów języka specjalistycznego przygotowują go do komunikowania w języku specjalistycznym (Berdychowska 2010: 66).

Analiza błędów popełnianych przez kandydatów na państwowym egzaminie dla osób pragnących uzyskać prawo do wykonywania zawodu tłumacza przysięgłego przeprowadzona przez Kubackiego (2009: 11-28) ukazuje, że problemem przyszłych adeptów przekładu jest nie tylko niewystarczająca wiedza specjalistyczna w danej dziedzinie (por. też Berdychowska 2010) - tutaj w dziedzinie prawa - ale również niewystarczający poziom opanowania języka i to zarówno ogólnego (błędy gramatyczne, głównie morfologiczne w zakresie użycia liczby mnogiej, właściwej końcówki przymiotnika, prawidłowego przypadka), jak i specjalistycznego (niewłaściwe dla danej dziedziny specjalistycznej użycie przyimków, przypadków, błędy w użyciu rodzajników określonych i zerowych w języku niemieckim) (Kubacki 2009: 17 i nast.). Aby zatem student jako przyszły tłumacz wykształcił sprawność prawidłowego przekładu, 
musi przede wszystkim opanować język (także w wariancie specjalistycznym) na wymaganym poziomie. Kompensacji niedostatków w zakresie wiedzy specjalistycznej lub kompetencji językowych użytkownik szuka w jedno- lub dwujęzycznym słowniku językowym, rzeczowym lub encyklopedycznym, leksykonie encyklopedycznym lub w innym dziele leksykograficznym (por. Cieślik 2014: 90).

\section{Otwartość funkcji słownika}

W zależności od kontekstu i celu, w jakim użytkownik sięga po słownik, wyróżnia się jego funkcję bezpośrednią i pośrednią (por. Tarp 1994: 232). Pierwsza z nich polega na bezpośrednim przekazywaniu informacji językowych i encyklopedycznych w procesie nauki języka. Funkcję pośrednią słownik pełni wówczas, gdy wykorzystywany jest jako narzędzie komunikacji w procesie przekładu tekstu (Tarp 1994: 232).

Obok funkcji bezpośredniej i pośredniej słownikowi przypisuje się funkcję aktywną lub pasywną (Worbs 1997: 500; Lipczuk 2004: 839), które związane są z kierunkiem opisu języka. I tak słownik polsko-niemiecki spełnia funkcję aktywną dla polskojęzycznego użytkownika przy produkcji tekstu i funkcję pasywną dla użytkownika niemieckojęzycznego przy recepcji tekstu, a słownik niemiecko-polski odpowiednio odwrotnie.

Artykuł skupia się na funkcji bezpośredniej dwóch wybranych bilingwalnych słowników języka specjalistycznego: Słownika terminologii gospodarczej (Kienzler 2004) i Dużego słownika finansowo-handlowego (Dreger, Dreger 2007) .

\section{Struktury w słowniku}

Struktury słownika kształtowane są przez relacje wertykalne i linearne zachodzące między elementami słownika ${ }^{4}$. Typem struktury wertykalnej jest makrostruktura (por. Hausmann, Werner 1991: 2746, Frączek, Lipczuk 2004: 9, 14, 18, Żmigrodzki 2009: 52-53), natomiast linearnej - mikrostruktura (por. Bergenholtz, Tarp, Wiegand 1999: 1791-1801, Frączek, Lipczuk 2004: 18). Za typ struktury konstytuowanej zarówno przez relacje wertykalne, jak i linearne uznaje się mediostrukturę (por. Kammerer 1998: 318; Wiegand 1998a: 408; Wiegand 2004).

Celem niniejszego rozdziału jest zbadanie otwartości poszczególnych struktur, czyli ukazanie dostępności danych leksykograficznych prezentowanych w słowniku. 


\subsection{Otwartość makrostruktury}

W dyskursie metaleksykograficznym wyróżnia się następujące typy makrostruktur: alfabetyczny, gniazdowo-alfabetyczny i niszowo-alfabetyczny (por. m.in. Hausmann, Werner 1991: 2746; Piotrowski 1994: 21; Wiegand 1998b: 351; Bergenholtz, Tarp, Wiegand 1999: 1816 i nast.; Piotrowski 2001: 37; Frączek, Lipczuk 2004: 9, 14, 18; Żmigrodzki 2009: 53 i nast.).

W obu analizowanych słownikach dominuje układ gniazdowo-alfabetyczny ${ }^{5}$. Dostrzec można też cechy struktury alfabetycznej, jak również pewne elementy układu niszowoalfabetycznego.

Strukturę gniazdowo-alfabetyczną ukazują prezentowane poniżej fragmenty z wybranych słowników.

Rzeczownik bank lematyzowany jest w Słowniku terminologii gospodarczej (Kienzler 2004) jako hasło główne. Podhasła to połączenia wielowyrazowe z rzeczownikiem bank:

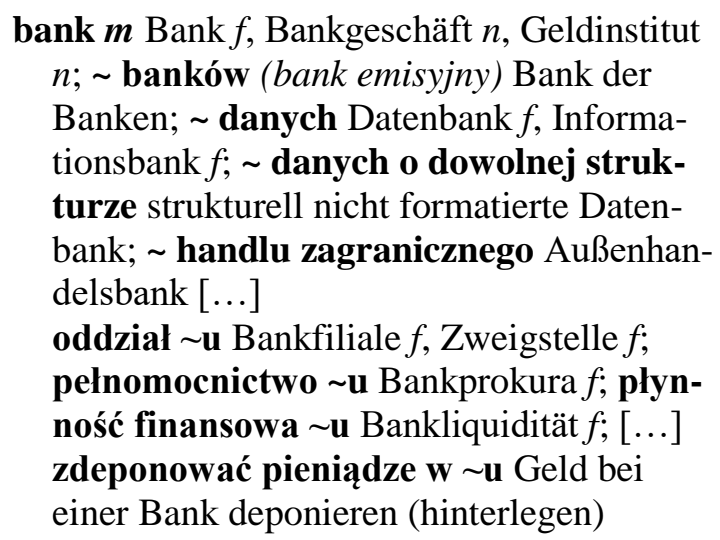

Stownik terminologii gospodarczej (Kienzler 2004: 383)

Osobnymi hasłami głównymi są: bankier, bankowość, bankowy. Również niepowiązany znaczeniowo z rzeczownikiem bank rzeczownik bankiet odnotowywany jest jako osobne hasło główne.

Cechy makrostruktury alfabetycznej widoczne są głównie w niemiecko-polskiej części Słownika terminologii gospodarczej (Kienzler 2004). Niemieckie rzeczowniki złożone z elementem Bar- w znaczeniu ,gotówkowy” lematyzowane są w 4 osobnych artykułach hasłowych i oddzielone hasłami niezwiązanymi znaczeniowo z rzeczownikiem Bar-, co daje następujący układ haseł:

Bar/abdeckung $f$ spłata gotówką; abhe-

bung $f$ podjęcie gotówki

Baratt $\boldsymbol{m}$ barter, handel kompensacyjny

Bar/ausgänge $\boldsymbol{m p l}$ nakłady gotówkowe, in- 
westycje gotówkowe, płatności gotówkowe; auszahlung $f$ zapłata gotówką, wypłata gotówką; -bestand $m$ stan gotówki; 〜ertrag $m$ wpływy gotówkowe

bargeldlos bezgotówkowo, czekiem

Bar/geldmittel $\boldsymbol{n p l}$ gotówka, środki pieniężne gotówkowe; geldumlauf $m$ obrót pieniądza gotówkowego; $\sim$ mittel $n p l$ środki w gotówce, środki płynne; schaft $f$ gotówka, kapitał; scheck $m$ czek gotówkowy

Barter/abkommen $\boldsymbol{n}$ umowa barterowa; นhandel $m$ handel barterowy, handel kompensacyjny

Bar/verkauf $\boldsymbol{m}$ sprzedaż gotówkowa; vorschuss $m$ zaliczka w gotówce; zahlung $f$ zapłata gotówką

Słownik terminologii gospodarczej (Kienzler 2004: 29)

Rzeczowniki złożone, jak np. Bargeldmittel, Barverkauf nie zostały umieszczone jako podhasła do hasła Bar- w pierwszym artykule i nie zaburzają porządku alfabetycznego względem niepowiązanego z nimi morfosemantycznie hasła Barrat.

Gniazdowo-alfabetyczny układ haseł dominuje również w polsko-niemieckiej części Dużego słownika finansowo-handlowego (Dreger, Dreger 2007). W artykule hasła bank dostrzec daje się podobna jak w Słowniku terminologii gospodarczej (Kienzler 2004) relacja między hasłem i podhasłami włączonymi do tego samego artykułu:

bank - 1. Bank $f$, -, -en, Bankinstitut $n$, -(e)s, -e, Kreditinstitut $n$, -(e)s, -e, Kreditanstalt $f$, -, -en, Geld- und Kreditinstitut $n$,-s, -e 2. Bankgebäude $n$, -s, -, Bankhaus $n$, -es, -"er; afiliowany Tochterbank $f ; \sim$ akceptacyjny Akzeptbank $f$; akcyjny Aktienbank $f ;[\ldots]$ [...] Międzynarodowy Bank Odbudowy i Rozwoju Internationale Bank für Wiederaufbau $m$, -(e)s und Entwicklung $f$, -, -en

Duży słownik finansowo-handlowy (Dreger, Dreger 2007: 476-477)

Kolejne hasła główne to: bankier, bankierski, bankierstwo, banknot, bankomat, bankowość, bankowy. Hasła bankier, bankierski, bankierstwo nie zostały pogrupowane w gniazda, lecz prezentowane są $\mathrm{w}$ układzie podobnym do układu alfabetycznego. W części niemieckopolskiej zastosowano układ alfabetyczny z wyjątkiem haseł, przy których podawane są jednostki wielowyrazowe.

Bericht $\boldsymbol{m}$, -(e)s, -e - informacja, sprawozdanie, biuletyn, raport, komunikat; des Verwaltungsrates sprawozdanie zarządu; laut $\sim \mathrm{s}$ zgodnie $\mathrm{z}$ zawiadomieniem 
Duży słownik finansowo-handlowy (Dreger, Dreger 2007: 63)

Rejestrowane jako hasła główne jednostki berichten, Berichterstatter, Berichtsabschnitt, Berichtsjahr, Berichtszeit prezentowane są w układzie alfabetycznym.

W obu słownikach odnotowywane są same warianty specjalistyczne hasła, a nieuwzględniane są warianty znaczeniowe z języka ogólnego:

drogi 1. hoch im Preis; 2. teuer, kostenspielig

Stownik terminologii gospodarczej (Kienzler 2004: 422)

drogi - teuer, kostenspielig, hoch im Preis

Duży słownik finansowo-handlowy (Dreger, Dreger 2007: 504)

\subsection{Otwartość mikrostruktury}

Dane dostępne dla użytkownika na poziomie mikrostruktury to, obok potencjalnych odpowiedników w drugim języku i informacji o rodzaju gramatycznym rzeczowników niemieckich, glosy odróżniające znaczenia lematyzowanych haseł (niem. differenzierende Glossen por. m.in. Nerlicki 2015: 217)

W obu częściach Stownika terminologii gospodarczej (Kienzler 2004) glosy odnotowywane są w tej samej formie i podawane w języku polskim.

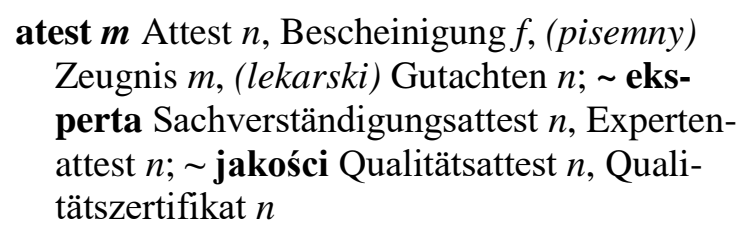

Stownik terminologii gospodarczej (Kienzler 2004: 380)

W polsko-niemieckiej części Dużego słownika finansowo-handlowego (Dreger, Dreger 2007) glosy po stronie hasła odnotowywane są w języku polskim, natomiast po stronie odpowiedników niemieckich w języku niemieckim:

barateria (działanie kapitana lub zatogi statku na szkodę czartującego) - Baratterie $f$, -, -n, Beschädigung der Ladung (durch die Besatzung)

Duży słownik finansowo-handlowy (Dreger, Dreger 2007: 477)

W części niemiecko-polskiej tegoż słownika glosy po stronie haseł niemieckich pojawiają się znaczenie rzadziej, zaś te po stronie polskich odpowiedników rejestrowane są w języku polskim. Częściej od glos, po stronie niemieckich haseł, odnotowywane są wyrażenia bliskoznaczne:

\section{Geschäftsführung (Geschäftsgebarung) $f$, -, -en}

- 1. kierowanie (zarządzanie) firmą; mit der 
beauftragt sein mieć polecenie kierowania firmą (interesem), mieć pełnomocnictwo do prowadzenia firmy 2. kierownictwo zakładu (firmy)

Duży stownik finansowo-handlowy (Dreger, Dreger 2007: 153)

Powyższy artykuł hasłowy ukazuje, że na poziomie mikrostruktury ukazywane są także relacje paradygmatyczne. W Słowniku terminologii gospodarczej (Kienzler 2004) informacje paradygmatyczne prezentowane są natomiast w ograniczonym wymiarze.

Oba słowniki uwzględniają zjawisko pluricentryzmu języka niemieckiego, które w kontekście słowników języka specjalistycznego badane jest m.in. u Kubackiego (2015: 37). Informacje tego typu użytkownik znajduje na poziomie mikrostruktury $\mathrm{w}$ formie kwalifikatorów informujących o użyciu danego hasła w Austrii lub Szwajcarii. Występują one zarówno po stronie odpowiedników w części polsko-niemieckiej, jak i po stronie haseł w części niemiecko-polskiej:

dowód - Schein $m$, (-e)s, -e, Zertifikat $n$, -s, -e, Be-

scheinigung $f,-$, -en, Gutachten $n,-$ s, -, Beweis

$m$, -es, -e; $[\ldots]$

$[\ldots] \sim$ osobisty österr.

Personalausweis $m$, -es, -e, Identitätsausweis $m$, -es, -e schweiz. Identitätskarte $f,-,-\mathrm{n} ;[\ldots]$

Duzy stownik finansowo-handlowy (Dreger, Dreger 2007: 503)

Gehalt $n$, -(e)s, -"er österr. $m$ - płaca, wynagrodzenie, pobory, pensja [...]

Duży słownik finansowo-handlowy (Dreger, Dreger 2007: 142)

W Słowniku terminologii gospodarczej (Kienzler 2004) kwalifikatory diatopiczne występują znacznie rzadziej niż w Dużym słowniku finansowo-handlowym (Dreger, Dreger 2007) i dotyczą haseł w niemiecko-polskiej części słownika:

Fruchtnießer $m$ aust. użytkownik

Słownik terminologii gospodarczej (Kienzler 2004: 113)

Lokalaugenschein $\boldsymbol{m}$ austr. wizja lokalna, oględziny

Słownik terminologii gospodarczej (Kienzler 2004: 198)

lub podhaseł w części niemiecko-polskiej:

Schuld/verschreibungsinhaber $\boldsymbol{m}$ posiadacz

listu zastawczego; versprechen $n$

1. szwajc. przyznanie się do winy;

2. przyrzeczenie $[\ldots]$

Stownik terminologii gospodarczej (Kienzler 2004: 113) 
Przytoczone tutaj przykłady pokazują, że w Słowniku terminologii gospodarczej (Kienzler 2004) skróty kwalifikatorów stosowane są niekonsekwentnie (aust. vs. austr.), przy czym zgodnie z „Wykazem skrótów i znaków objaśniających” poprzedzającym spis haseł austr. to właściwa i planowana przez autorkę słownika forma.

W obu słownikach brak jest przykładów ukazujących użycie opisywanych haseł w kontekście. Włączenie w zakres mikrostruktury przykładów pochodzących z autentycznych tekstów specjalistycznych mogłoby w znacznym stopniu wesprzeć funkcję dydaktyczną słownika.

\subsection{Otwartość mediostruktury}

Mediostrukturę ${ }^{6}$ definiuje się jako system odsyłaczy w słowniku o charakterze eksplicytnym lub implicytnym kierujących użytkownika do innego miejsca w słowniku (odsyłacze wewnętrzne) lub do innych źródeł poza słownikiem (odsyłacze intertekstualne) (Kammerer 1998a: 318; Wiegand 1998a: 408; Wiegand 2004).

Prezentowane tutaj słowniki posiadają odmienne mediostruktury. Słownik terminologii gospodarczej (Kienzler 2004) sygnalizuje odsyłacze skrótem zob. podanym w „Wykazie skrótów i znaków objaśniających”, co świadczy o obecności eksplicytnego systemu odsyłaczy w słowniku. Odsyłacze stosowane są głównie jako element makrostruktury, tzn. przy haśle będącym nazwą własną lub skrótowcem użytkownik odsyłany jest do innego hasła głównego:

\section{LINGUA $z o b$. Programm zur Förderung der fremdsprachlichen Ausbildung}

Stownik terminologii gospodarczej (Kienzler 2004: 198)

\section{MAST $z o b$. Spezifisches Programm für Forschung und Entwicklung im Bereich der Meereswissenschaft und Technologie}

Stownik terminologii gospodarczej (Kienzler 2004: 204)

Taki system odsyłaczy ukazuje, że prezentowany słownik jest poliakcesywny, tzn. posiada dwie lub więcej ścieżki dostępu do tego samego hasła (niem. „Zugriffspfad” por. Bergenholtz, Tarp, Wiegand 1999: 1784; Wiegand 2005: 216). Odpowiednik w języku polskim prezentowany jest jednak tylko przy haśle, do którego użytkownik jest odsyłany, a zatem na płaszczyźnie makrostrukturalnej. W badaniu nie odnotowano odsyłaczy wewnętrznych na płaszczyźnie mikrostruktury słownika.

Charakter mediostruktury zewnętrznej mają teksty (np. wzory bilansu polskiego i niemieckiego) umieszczone po spisie haseł. 
Duży stownik finansowo-handlowy (Dreger, Dreger 2007) nie stosuje odsyłaczy eksplicytnych. Odniesienia do innych miejsc w słowniku, w tym przypadku między makrostrukturami, realizowane są przez podanie przy haśle głównym jego wariantu:

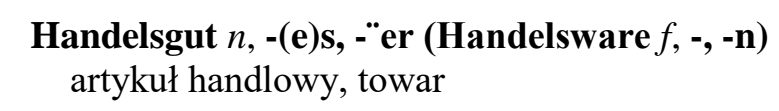

Duży słownik finansowo-handlowy (Dreger, Dreger 2007: 170)

Taki sposób rejestrowania haseł świadczy - podobnie jak u Kienzler - o poliakcesywności słownika. Odsyłacze wewnętrzne stosowane są jednokierunkowo, co oznacza, że pod hasłem Handelsware użytkownik nie znajdzie odniesienia do hasła Handelsgut. Słownik nie zawiera odsyłaczy intertekstualnych. Wynika to z faktu, że na poziomie mikrostruktury nie odnotowuje się przykładów leksykograficznych zaczerpniętych z autentycznych tekstów.

\section{Wnioski}

Badanie ukazało, że oba zaprezentowane słowniki mogą znaleźć zastosowanie w dydaktyce języka specjalistycznego. Analiza ukierunkowana na makrostrukturę słownika prowadzi do wniosku, że typem układu haseł wspierającym naukę języka niemieckiego jest układ gniazdowo-alfabetyczny, przy którym użytkownik może dostrzec zależności morfosemantyczne między hasłem a podhasłami i dotrzeć do informacji o kompatybilności semantycznej lemmatu z innymi jednostkami. W kontekście dyskutowanej tutaj otwartości słownika na uwagę zasługuje - ze względu na przejrzystość opisu - układ alfabetyczny, czyli ten, który przeważa w części niemiecko-polskiej Dużego słownika finansowo-handlowego (Dreger, Dreger 2007). Taki układ, mimo wady zwiększenia objętości słownika, pozwala użytkownikowi na dotarcie do szukanego hasła bez konieczności zagłębiania się w często mocno rozbudowane struktury artykułów hasłowych.

Analiza przeprowadzona na płaszczyźnie mikrostruktury słownika pozwala na sformułowanie wniosku, że zaprezentowane dzieła leksykograficzne zawierają więcej niż jedną ścieżkę dostępu do informacji. Do podobnych wniosków prowadzi badanie przeprowadzone na płaszczyźnie makrostrukturalnej. Należy jednak zaznaczyć, że poliakcesywność nie jest cechą każdego hasła lematyzowanego w omawianych tutaj słownikach.

Obecność w opisie leksykograficznym glos polskojęzycznych w obu częściach Słownika terminologii gospodarczej (Kienzler 2004) świadczy o przewadze monodyrekcjonalności i 
ukierunkowaniu na użytkownika polskojęzycznego. Odnotowywanie rodzaju gramatycznego w polsko-niemieckiej części słownika przy polskich hasłach rzeczownikowych pokazuje, że słownik posiada również cechy bidyrekcjonalności, a zatem otwartości na użytkownika niemieckojęzycznego. Także w Dużym słowniku finansowo-handlowym (Dreger, Dreger 2007) przeważa monodyrekcjonalność z ukierunkowaniem na polskojęzycznego użytkownika. Potwierdza to przewaga glos polskojęzycznych w obu częściach słownika. Natomiast fakt, że w części polsko-niemieckiej po stronie niemieckich odpowiedników glosy podawane są niekiedy w języku niemieckim, czyni słownik jeszcze bardziej monodyrekcjonalnym. Opisy takie adresowane są do polskojęzycznego użytkownika, a ich celem jest wspieranie funkcji dydaktycznej słownika przez przedstawianie pewnych gotowych sformułowań i wzorów sformułowań w języku docelowym.

\section{Przypisy}

1 Dwa pozostałe konteksty badane przez Wieganda to korzystanie ze słownika w celu sprawdzenia jego kompletności, przygotowania do sprzedaży i opracowania recenzji (w oryginale: "ein Wörterbuch als Prüfgegenstand benutzen" [Wiegand 1998a: 369]), a także korzystanie ze słownika jako lektury (w oryginale: „ein Wörterbuch als Lesebuch zur Sprache benutzen” [Wiegand 1998a: 369]).

${ }^{2} \mathrm{Na}$ temat kontekstów korzystania ze słownika dwujęzycznego zob. Lipczuk (2004: 837).

${ }^{3}$ Koncepcje wspomnianych słowników przedstawione zostały w monografii Konieczna-Serafin (2018a).

${ }^{4}$ Problematykę struktur w słowniku podejmuje artykuł Konieczna-Serafin (w druku).

${ }^{5}$ Zgodnie z Frączek i Lipczukiem cechą makrostruktury gniazdowo-alfabetycznej jest fakt, że hasła prezentowane w obrębie jednego artykułu wykazują wspólne cechy morfosemantyczne, przy czym podhasła ,'wyprzedzają' pod względem alfabetu kolejne hasła główne" (Frączek, Lipczuk 2004: 14). Przy układzie gniazdowo-alfabetycznym podhasło stanowi złożenie lub derywat hasła. W słowniku języka specjalistycznego podhasłami są głównie połączenia wielowyrazowe i niemieckie rzeczowniki złożone. Natomiast przy układzie haseł niszowoalfabetycznym podhasła, czyli derywaty lub złożenia, „nie zaburzają kolejności alfabetycznej w słowniku” (Frączek, Lipczuk 2004: 18) i nie muszą być powiązane semantycznie lub morfologicznie z hasłem głównym.

${ }^{6}$ Szerzej na temat mediostruktur w słownikach języka specjalistycznego por. Konieczna-Serafin (2018b).

\section{Bibliografia}

Berdychowska, Zofia (2010) „Komunikacja specjalistyczna na studiach filologicznych podstawy lingwistyczne i profile". Lingwistyka Stosowana, 3; 61-70. http://alp.uw.edu.pl/wp-content/uploads/sites/315/2018/03/Lingwistyka-Stosowana-

3_2010.pdf [25.06.2018]. 
Bergenholtz, Henning, Sven Tarp, Herbert E. Wiegand (1999) „Datendistributionsstrukturen, Makro- und Mikrostrukturen in neueren Fachwörterbüchern”. [W:] Lothar Hoffmann, Hartwig Kalverkämper, Herbert E. Wiegand, Christian Galinski, Werner Hüllen (red.) Fachsprachen: ein internationales Handbuch zur Fachsprachenforschung und Terminologiewissenschaft. Berlin, New York: de Gruyter; 1762-1832.

Cieślik, Bolesław (2014) „Materiały pomocnicze na egzaminie na thumacza przysięgłego”. [W:] Monika Krajewska, Lech Zieliński (red.) Rocznik Przekładoznawczy. Studia nad teoria, praktyka i dydaktyka przekładu, 9; 89-99.

Dębski, Antoni (2001) „Słownik: Ostoja tłumacza i podpora nauczania czy też źródło błędów i frustracji?”. [W:] Paweł Płusa (red.) Prace Naukowe WSP w Częstochowie. Studia Neofilologiczne, 2; 23-28.

de Groot, Gérhard-René (1999) „Zweisprachige juristische Wörterbücher”. [W:] Peter Sandrini (red.) Übersetzen von Rechtstexten. Fachkommunikation im Spannungsfeld zwischen Rechtsordnung und Sprache. Tübingen: Narr; 203-227.

Dreger, Henryk, Piotr Dreger (2007) Duży słownik finansowo-handlowy niemiecko-polski, polsko-niemiecki. Warszawa: Wydawnictwo Poltext.

Frączek, Agnieszka, Ryszard Lipczuk (2004) Słowniki polsko-niemieckie i niemiecko-polskie. Historia i teraźniejszość. Wołczkowo: Oficyna IN PLUS.

Gugała, Paweł (2002) „Wörterbuch als Hilfe beim Übersetzen juristischer Texte (Analyse zweier polnisch-deutscher Wörterbücher)““. [W]: Christoph Schatte (red.) Linguistische und didaktische Probleme der Translatorik: Polnisch-deutsche Nachwuchskonferenz zur germanistischen Linguistik, Stubice, Oktober 2001. Poznań: Wydawnictwo Rys; 49-60.

Hausmann, Franz J., Reinhold O. Werner (1991) „Spezifische Bauteile und Strukturen zweisprachiger Wörterbücher“. [W:] Franz J. Hausmann, Oskar Reichmann, Herbert E. Wiegand, Ladislav Zgusta (red.) Wörterbücher. Dictionaries. Dictionnaires. Ein internationales Handbuch zur Lexikographie. Berlin/ New York: de Gruyter; 2729-2769.

Kammerer, Matthias (1998) „Die Mediostruktur in Langenscheidts Großwörterbuch Deutsch als Fremdsprache”. [W:] Herbert E. Wiegand (red.) Perspektiven der pädagogischen Lexikographie des Deutschen. Untersuchungen anhand von Langenscheidts Großwörterbuch Deutsch als Fremdsprache. Tübingen: Niemeyer; 315-330.

Kienzler, Iwona (2004) Stownik terminologii gospodarczej. Bankowość, Finanse, Prawo niemiecko-polski, polsko-niemiecki. Warszawa: Wydawnictwo C. H. Beck. 
Konieczna-Serafin, Joanna (2018a) Fachsprachliche Lexikographie. Konzeptionen von bilingualen Wörterbüchern der Fachsprache Wirtschaft für das Sprachenpaar Deutsch und Polnisch. Berlin: Peter Lang.

Konieczna-Serafin, Joanna (2018b) „Mediostrukturen im Wörterbuch der Fachsprache Wirtschaft". [W:] Beata Grzeszczakowska-Pawlikowska, Agnieszka StawikowskaMarcinkowska (red.) Speclang 2. Fachsprachen - Ausbildung - Karrierechancen. Łódź: Primum Verbum; 39-55.

Konieczna-Serafin (w druku) „Strukturen im Wörterbuch als Schlüsselwörter“.

Kopczyńska, Magdalena (2013) „Kształcenie umiejętności korzystania ze słowników u tłumaczy nieprofesjonalistów z perspektywy leksykografii i dydaktyki przekładu”. [W:] Monika Krajewska, Lech Zieliński (red.) Rocznik Przekładoznawczy. Studia nad teoria, praktyka i dydaktyka przekładu, 8; 123-136.

http://apcz.umk.pl/czasopisma/index.php/RP/article/viewFile/296/289 [25.06.2018].

Kubacki, Artur D. (2009) „Fehler in der Fachübersetzung der Kandidaten für einen staatlich vereidigten Übersetzer". [W:] Anna Mrożewska (red.) Philologische Ostsee-Studien/ Zeszyty Naukowe Instytutu Neofilologii i Komunikacji Społecznej, 2. Koszalin: Wydawnictwo Uczelniane Politechniki Koszalińskiej; 11-28. http://www.kubart.pl/dopobrania-materialy-dla-studentow-i-tlumaczy [25.06.2018].

Kubacki, Artur D. (2015) „Pluricentryzm w niemiecko-polskich słownikach ogólnych i specjalistycznych”. Lingwistyka Stosowana 15: 4/2015, 33-46.

https://portal.uw.edu.pl/documents/7276721/13367621/3+Lingwistyka+Stosowana+15+A rtur+Kubacki.pdf [21.08.2017].

Lipczuk, Ryszard (1997) „Einige kritische Bemerkungen zur deutsch-polnischen Lexikographie“. [W:] Antoni Dębski (red.) Plus ratio quam vis. Festschrift für Aleksander Szulc zum 70. Geburtstag. Kraków: Wydawnictwo Uniwersytetu Jagiellońskiego; 111-118. Lipczuk, Ryszard (2004) „Zum Problem der Äquivalente in zweisprachigen Wörterbüchern“. Studia Niemcoznawcze, 28; 833-842.

Lipczuk, Ryszard (2017) „Über einige Fehler in deutsch-polnischen Großwörterbüchern“. [W:] Ryszard Lipczuk, Magdalena Lisiecka-Czop, Karl H. Ramers (red.) Sprache und Wörterbücher in Theorie und Praxis. Lexikografische und textlinguistische Fragestellungen. Hamburg: Verlag Dr. Kovač; 93-104. 
Nadobnik, Renata (2010) Znaczenie słowników bilingwalnych w dydaktyce języka niemieckiego w Polsce. Gorzów Wielkopolski: Wydawnictwo Państwowej Wyższej Szkoły Zawodowej w Gorzowie Wielkopolskim.

Nerlicki, Krzysztof (2015) „Phraseologische Glossen - ein Differenzierungsversuch an Beispielen aus ausgewählten deutsch-polnischen Wörterbüchern”. [W:] Elżbieta MańczakWohlfeld, Barbara Podolak (red.) Words and Dictionaries. A Festschrift for Professor Stanisław Stachowski on the Occasion of His 85th Birthday. Kraków: Jagiellonian University Press; 215-230.

Piotrowski, Tadeusz (1994) Problems in bilingual lexicography. Wrocław: Wydawnictwo Uniwersytetu Wrocławskiego.

Piotrowski, Tadeusz (2001) Zrozumieć leksykografię. Warszawa: Wydawnictwo Naukowe PWN.

Piotrowski, Tadeusz (2011) „Ekwiwalencja w słownikach dwujęzycznych”. [W:] Wojciech Chlebda (red.) Na tropach translatów. W poszukiwaniu odpowiedników przekładowych. Opole: Wydawnictwo Uniwersytetu Opolskiego; 45-69.

Szubert, Rafał (2003) „Słowniki dwujęzyczne a tłumaczenie tekstów specjalistycznych”. Studia Niemcoznawcze, 25; 795-804.

Tarp, Sven (1994): „Funktionen in Fachwörterbüchern”. [W:] Burkhard Schaeder, Henning Bergenholtz (red.) Fachlexikographie. Fachwissen und seine Repräsentation in Wörterbüchern. Tübingen: Narr; 229-246.

Wiegand, Herbert E. (1998a) Wörterbuchforschung. Untersuchungen zur Wörterbuchbenutzung, zur Theorie, Geschichte, Kritik und Automatisierung der Lexikographie. Berlin: de Gruyter.

Wiegand, Herbert E. (1998b) „Altes und Neues zur Makrostruktur alphabetischer Printwörterbücher”. [W:] Herbert E. Wiegand (red.) Wörterbücher in der Diskussion III: Vorträge aus dem Heidelberger Lexikographischen Kolloquium. Tübingen: Niemeyer; $348-372$.

Wiegand, Herbert E. (2004) „Reflections on the mediostructure in special-field dictionaries. Also according to the example of the dictionary for lexicography and dictionary research". Lexikos, 14; 195-221. http://lexikos.journals.ac.za/pub/article/view/690 [25.06.2018].

Wiegand, Herbert E. (2005) „Über die Datenakzessivität in Printwörterbüchern. Einblicke in neuere Entwicklungen einer Theorie der Wörterbuchform". Lexikos, 15; 196-230. http://lexikos.journals.ac.za/pub/article/viewFile/13/22 [25.06.2018]. 
Wiegand, Herbert E. (2013) „Fachwissen, fachliche Daten und ihre textuelle Präsentation in Fachwörterbüchern vom Typ des Lern- und Konsultationswörterbuchs”. [W:] Vida Jesenšek (red.) Specialised Lexicography. Print and Digital, Specialised Dictionaries, Databases. Berlin, Boston: de Gruyter; 23-42.

Worbs, Erika (1997) „Plädoyer für das zweisprachige Wörterbuch als Hilfsmittel des Translators". [W:] Horst W. Drescher (red.) Transfer. Übersetzen. Dolmetschen. Interkulturalität. 50 Jahre Fachbereich Angewandte Sprach- und Kulturwissenschaft der Johannes Gutenberg-Universität Mainz in Germersheim. Frankfurt/ M.: Peter Lang; 497510.

Żmigrodzki, Piotr (2009) Wprowadzenie do leksykografii polskiej. Katowice: Wydawnictwo Uniwersytetu Śląskiego. 